\title{
Regulation of HNK-1 (Human Natural Killer-1) Carbohydrate Expression: Multiple Control Mechanisms of Biosynthetic Enzyme Activity
}

\author{
生合成酵素活性の調節による HNK-1 糖鎖の発現制御
}

\author{
Kizuka, Yasuhiko'; and Oka, Shogo ${ }^{2}$ \\ ${ }^{1}$ Disease Glycomics Team, Systems Glycobiology Research Group, Advanced Science Institute, RIKEN, Saitama, Japan, \\ ${ }^{2}$ Department of Biological Chemistry, Human Health Sciences, Graduate School of Medicine, Kyoto University, Kyoto, Japan \\ FAX: 81-48-467-9617, E-mail:y.kizuka@ riken.jp
}

(Received on April 30, 2010, accepted on July 7, 2010)

Key Words: HNK-1, GlcAT-P, HNK-1ST, glycan biosynthesis

\begin{abstract}
HNK-1 carbohydrate is highly expressed in the nervous system and is involved in higher-order brain functions such as learning and memory. HNK-1 has a unique structure with sulfated glucuronic acid attached to the non-reducing end of $N$-acetyllactosamine ( $\mathrm{HSO}_{3}$-3GlcA $\beta 1-3 \mathrm{Gal} \beta 1-4 \mathrm{GlcNAc}$-). Two glucuronyltransferases and a sulfotransferase play key roles in its biosynthesis. We focused on how these enzyme activities are regulated in terms of HNK-1 expression. We revealed that the transferases form a hetero-complex for the efficient biosynthesis and that the activity is regulated by well-controlled intracellular localization. These facts indicate that HNK-1 expression is strictly regulated through multiple control mechanisms of the biosynthetic enzyme activity.
\end{abstract}

\section{A. Introduction}

The functions of glycans are difficult to analyze because of their structural diversity. For example, even if we focus on one glycoprotein molecule, its glycan structure is dynamically changed by many factors such as extracellular stimuli, development, differentiation or disease progression. This structural diversity is based on the complicated expression mechanism of glycans. There are many key determinant factors involved in glycan biosynthesis such as glycosyltransferase, glycosidase and sugar-nucleotide (1). Each glycosyltransferase has unique features which make it difficult to estimate the glycan structure only from its expression level including the existence of a homologous enzyme, protein substrate selectivity or branch specificity. Recent studies have revealed regulation mechanisms of glycosyltransferase activity except for expression level such as enzyme-complex formation (2), shedding (3) or oligomerization (4). Therefore, understanding the regulation mechanisms of enzyme activity will help to elucidate wellorganized glycan expression process in cells.
要 約

HNK-1 糖鎖は神経系に高発現しており、記憶学習やスパ イン構造の成熟に深く関与している。その構造はN-アセチル ラクトサミンの非還元末端に硫酸化グルクロン酸が付加した ( $\mathrm{HSO}_{3}-3 \mathrm{GlcA} \quad \beta \quad 1-3 \mathrm{Gal} \beta$ 1-4GlcNAc-) 特徵的なもので、生合成 の中心となるのは二種のグルクロン酸転移酵素と硫酸基転移 酵素である。我々は、これら転移酵素の活性が細胞内に抏い てどのような機構で調節され、HNK-1 糖鎖の発現がどのよう に制御されているかに着目した。その結果、これら転移酵素 群が複合体を形成して効率的に糖鎖生合成を行っていること、 また厳密な細胞内局在制御により生合成活性が調節されてい ることなどを明らかにした。これらの事実は、HNK-1 糖鎖の 発現が合成酵素の多面的な活性調節機構により厳密に制御さ れることを示唆している。

\section{A. はじめに}

糖鎖機能の解析における困難さの一つに糖鎖構造の多様 性が挙げられる。例えばある一種の糖タンパク質だけを見て も、細胞外からの刺激や発生・分化、疾患の進行などに応じ て糖鎖の構造は大きく変化する。その背景にあるのは糖鎖発 現メカニズムの複雑さである。糖鎖の生合成には、糖転移酵 素、糖分解酵素、糖又クレオチド濃度など様々な要素が絡む (1)。 さらに、糖転移酵素だけを見ても類似した基質特異性を持つ ホモログの存在、タンパク質選択性、分岐鎖特異性など個々 の転移酵素が独自の特色を有しており、特定の酵素の発現か ら糖鎖構造全体を推定するのは困難である。また近年では糖 転移酵素の複合体形成 (2)、shedding(3)、オリゴマー化 (4) など、 発現量以外にも細胞内酵素活性を調節する機構が次第に明ら かにされつつある。すなわち、細胞の持つ複雑な糖鎖発現入 カニズムを理解するには、個々の転移酵素の細胞内活性調節 機構を総合的に理解することが重要であると考えられる。

我々は以前から、神経系に高発現する HNK-1 (Human 


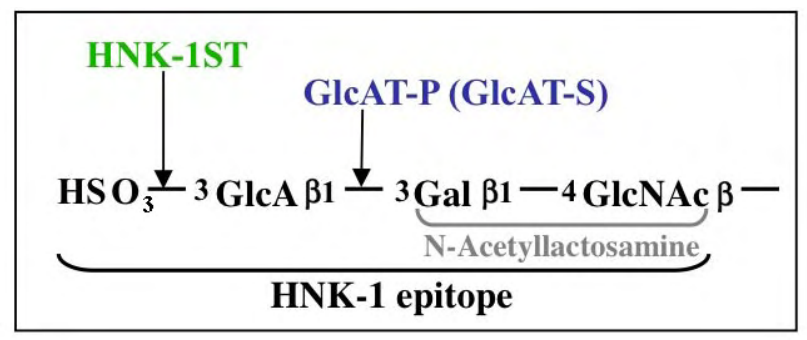

Fig. 1. Structure and biosynthesis of HNK-1 carbohydrate.

We have been studying on HNK-1 (Human Natural Killer-1) carbohydrate. This glycan epitope, comprising a unique trisaccharide structure with terminal sulfated glucuronic acid (Fig. 1), is highly expressed in the developing brain (5). Intriguingly, $\mathrm{HNK}-1$ is attached to the limited kinds of carrier molecules including NCAM, MAG and AMPA-type glutamate receptor (GluR2) (6). Two glucuronyltransferases (GlcAT-P, GlcAT-S) and a sulfotransferase (HNK-1ST) are involved in its biosynthesis (7), and our previous study using knockout mice revealed that GlcAT-P is the main enzyme for HNK-1 biosynthesis (8). Analysis of these mutant mice also demonstrated that HNK-1 plays important roles in higher-order brain functions including synaptic plasticity and maturation of dendritic spine $(8,9)$.

In this study, we investigated the regulatory mechanisms of the activity of the biosynthetic enzymes, leading to the elucidation of the HNK-1 expression mechanism. As a result, we revealed that enzyme-complex formation and control of subcellular localization were novel regulation mechanisms in the control of HNK-1 carbohydrate expression.

\section{B. Complex Formation of Transferases}

HNK-1 consists of a sulfated trisaccharide, which is sequentially biosynthesized by the different kinds of transferases (two glucuronyltransferase and a sulfotransferase). To date, however, almost all the structures of HNK-1 reported are sulfated, suggesting that HNK-1ST transfers the sulfate group to most glycans which have been glucuronylated by GlcAT-P (S).

Based on this fact, we hypothesized that GlcAT-P $(\mathrm{S})$ is associated with HNK-1ST during the sequential biosynthesis. Both these enzymes expressed in mammalian cells were coimmunoprecipitated, revealing that GlcAT-P (S) interacts with HNK-1ST in cells (Fig. 2) (10). To the contrary, these enzymes were not co-precipitated with other transferases which are irrelevant to HNK-1 synthesis such as a sialyltransferase or a chondroitin-sulfotransferase, indicating that the HNK1-related enzymes form a specific complex. Functionally, we showed that mixing GlcAT-P (S) and HNK-1ST in vitro increased the activity of HNK-1ST approximately 2-fold but
Natural Killer-1) 糖鎖に着目した研究を進めてきた。本糖鎖は、 硫酸化グルクロン酸を非還元末端に持つ特徵的な三糖構造か らなり (図 1)、発達期の脳に高発現している (5)。また興味深 いことに、NCAM や MAG などの接着分子や AMPA 型グル タミン酸レセプターGluR2 など、限られたキャリア分子にの み発現が見られる (6)。その生合成において重要な役割を果た すのが、二種のグルクロン酸転移酵素 GlcAT-P, GlcAT-S と 硫酸基転移酵素 HNK-1ST である (図 1) (7)。中でも我々が作 製したGlcAT-Pノックアウトマウスの解析から、GlcAT-P が HNK-1 生合成における主要な糖転移酵素であることがわかっ た (8)。またこのノックアウトマウスの解析によって、本糖鎖 が神経可塑性の維持や樹状突起スパインの成熟など、脳の高 次機能に重要な役割を果たすことが明らかになっている $(8,9)$ 。

本研究では、HNK-1 生合成酵素に焦点を当て、その活性 制御機構を明らかにすることで、生体内における HNK-1 発現 制御機構の解明を目指した。その結果、転移酵素群の複合体 形成や㛜密な局在制御機構といった新たな本糖鎖の発現制御 機構を明らかにした。

\section{B. 転移酵素群の複合体形成}

HNK-1 糖鎖は上述のように硫酸化三糖構造から成る。こ の構造はグルクロン酸転移酵素と硫酸基転移酵素という別種 の酵素の作用により合成される。しかし脳における HNK-1 糖 鎖の構造解析では硫酸基の付加していない夕イプの糖鎖はほ とんど見出されていない。このことは、GlcAT-P(S)によりグ ルクロン酸が転移された糖鎖のほとんどに続けて硫酸が付加 することを意味している。

こうした事実から、我々は GlcAT-P(S) と HNK-1ST が複 合体を形成し、連続的な生合成を行っているのではないかと 考えた。実際、動物細胞にこれらの酵素を発現させると免疫 沈降により共沈することから、GlcAT-P(or S) と HNK-1ST は 細胞内で結合していることがわかった(図 2)(10)。一方これ らの酵素は、シアル酸転移酵素や別の硫酸基転移酵素など、 HNK-1の合成に関係しない分子とは相互作用していなかっ たことから、HNK-1 合成に関わる酵素が特異的な複合体を 形成していると考えられる。また、インビトロの系において GlcAT-P $(\mathrm{S})$ と HNK-1ST を混合すると、グルクロン酸転移活 
Fig. 2. Co-immunoprecipitation of FLAGGIcAT-P, FLAG-GIcAT-S, and HNK-1ST-EGFP. Lysates of FLAG-P (lanes 1 and 2), FLAG-S (lanes 3 and 4), ST-EGFP (lanes 5 and 6), double FLAG-P and ST-EGFP (lanes 7 and 8), and double FLAG-S and ST-EGFP (lanes 9 and 10) CHO transfectants were immunoprecipitated (IP) with anti-EGFP (odd-numbered lanes) or anti-FLAG (even-numbered lanes) antibodies, subjected to SDS-PAGE, and then Western blotted with anti-FLAG mAb (upper panel) or anti-EGFP mAb (lower panel). This figure was modified from Kizuka et al. $J$. Biol. Chem. (2006).

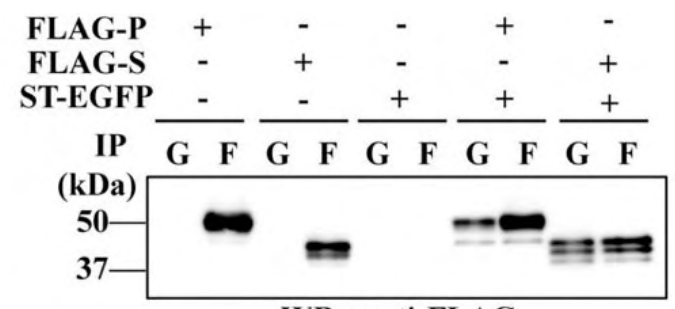

WB : anti-FLAG

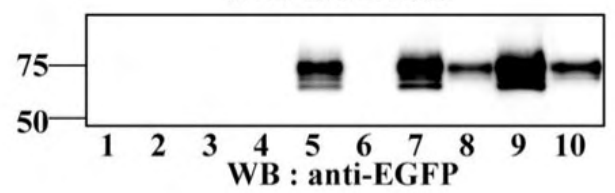

G : EGFP

F : FLAG
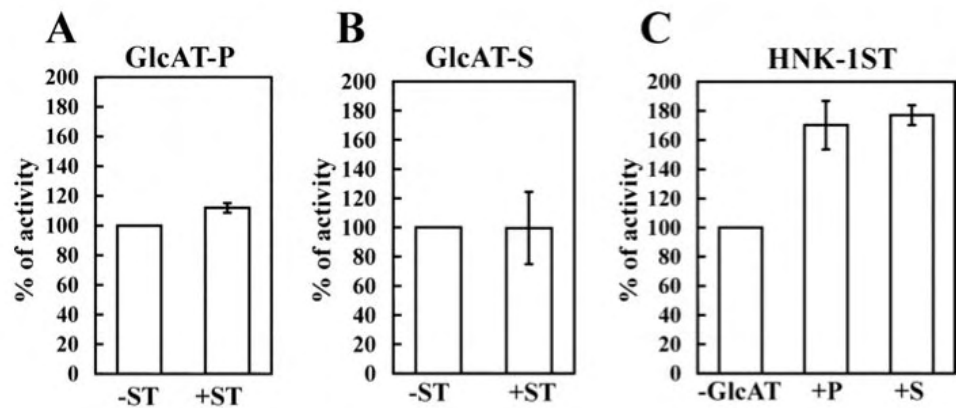

Fig. 3. In vitro transferase activity of GlcAT-P, GlcAT-S, and HNK-1ST with or without binding counterparts. The transferase activities of these enzymes toward glycoprotein substrates were measured. Taking the activity in the absence of a binding partner as $100 \%$, the activity in the presence of the partner is shown as the relative percentage. All experiments were carried out three times independently. The glucuronyltransferase activity of purified soluble form of GlcAT-P (A) or GlcAT-S (B) toward ASOR (asialoorosomucoid) was measured with (right bar) or without (left bar) purified HNK-1ST. (C) The sulfotransferase activity of HNK-1ST toward GlcA-ASOR was measured without glucuronyltransferase (left bar), with GlcAT-P (middle bar), or with GlcAT-S (right bar). This figure was modified from Kizuka et al. J. Biol. Chem. (2006)

not that of GlcATs (Fig. 3). These results suggest that the complex formation contributes to efficient biosynthesis of HNK-1 carbohydrate.

\section{GlcAT-P isoforms with Different Biosynthetic Activity}

Most glycosyltransferases including GlcAT-P are typeII membrane proteins which orient their short $\mathrm{N}$-terminal regions to the cytosol and their large catalytic domains to the luminal side of the ER or Golgi (11). It is evident that the N-terminal cytoplasmic tail can play a pivotal role in the regulation of the subcellular localization of the glycosyltransferase $(12,13)$. Glycosyltransferase cannot function properly without its appropriate localization where it can interact with its substrate. Therefore, it is important to analyze the localization mechanisms mediated by the cytoplasmic tail to understand the expression mechanism of glycans.

We previously reported that GlcAT-P has two isoforms differing only in their cytoplasmic tail length (the long form has an additional 13 amino acids, called P-N13 hereafter)
性はほぼ一定であったが硫酸基転移活性が二倍近くに上昇す ることがわかった (図 3) (10)。これらの結果は、複合体形成が HNK-1 生合成の効率化に寄与していることを示唆している。

C. 生合成活性の異なる GlcAT-P アイソフォーム

GlcAT-P は多くの糖転移酵素と同様、短い $\mathrm{N}$ 末端部分を 細胞質に配向させた II 型膜タンパク質であり、C 末端側の大 きな触媒ドメインをゴルジ内腔に配向させている $(11) 。$ 近年、 糖転移醳素の $\mathrm{N}$ 末の細胞質領域が、特に細胞内局在制御に関 して重要な役割を果たす事がわかってきた $(12 ， 13)$ 。糖転移酵 素は基質の存在するしかるべき場所に局在しなければ正しく 機能できないと考えられ、細胞質領域を介した酵素の局在制 御機構を解析することは糖鎖発現機構を知る上で大きな意味 がある。

GlcAT-Pには N 末の細胞質領域の長さが 13 アミノ酸 だけ異なるアイソフォームが存在することがわかっていたが (14)、その存在意義は不明であった。そこでこのアイソフォー 


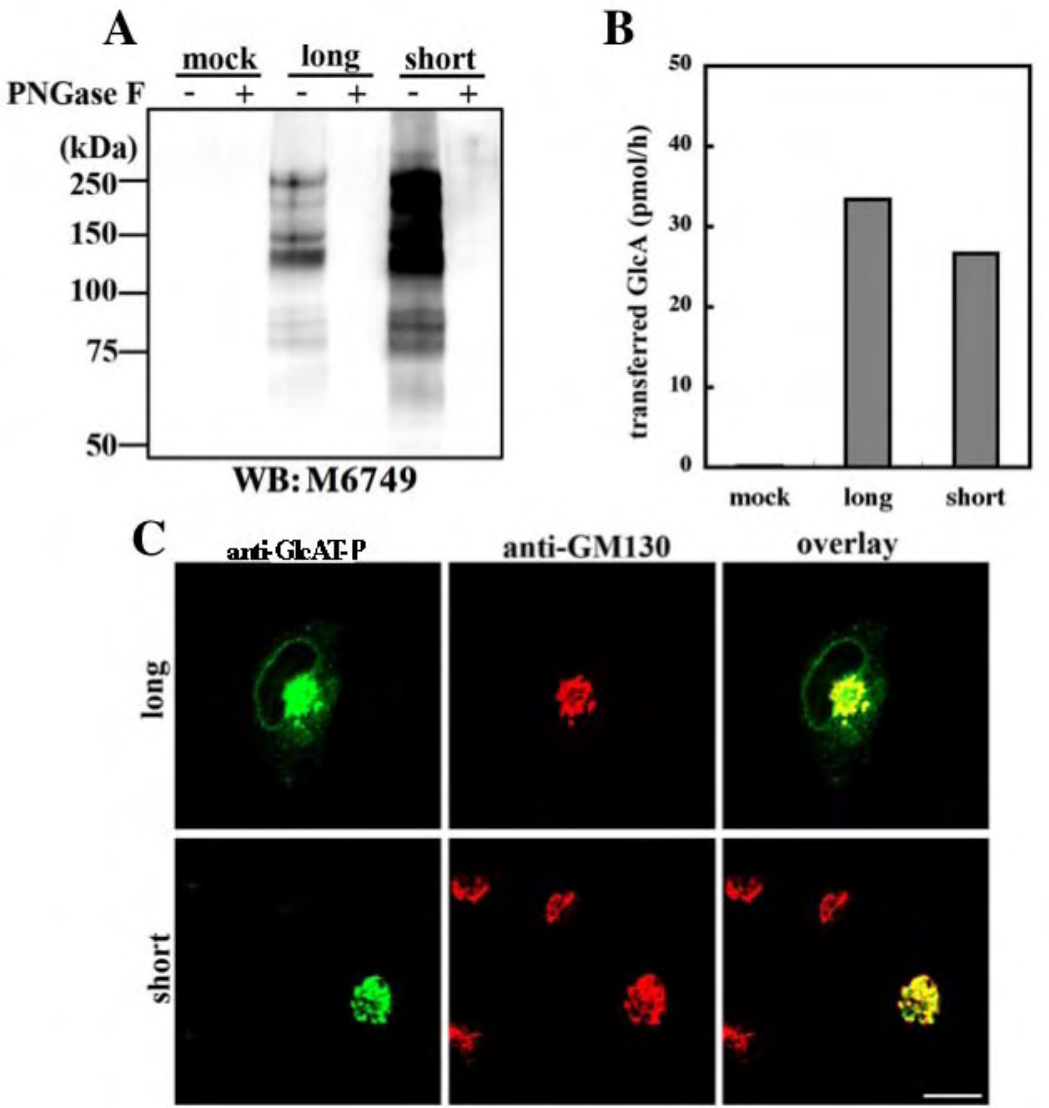

Fig. 4. Biosynthetic activities, in vitro activities, and localization of the two isoforms of rat GIcAT-P. (A) Neuro2A cells were transfected with the 1GlcAT-P (long form) or sGlcAT-P (short form) expression plasmid, or the empty vector (mock). Cells were lysed and treated with or without peptide: $N$-glycanase (PNGase F), and then subjected to Western blotting with M6749 $\mathrm{mAb}$. (B) In vitro glucuronyltransferase activity toward asialo-orosomucoid (ASOR), was measured. Mock treated-, 1GlcAT-P-expressing or sGlcAT-Pexpressing Neuro2A cells were lysed and used as an enzyme source. (C) Neuro2A cells expressing IGlcAT-P (upper panels) or sGlcAT-P (lower panels) were double-immunostained with anti-GlcAT-P (green) and anti-GM130 mAb (red). The right panels show overlaid images. Bar: $10 \mu \mathrm{m}$. This figure was modified from Kizuka et al. J. Biol. Chem. (2009)
(14), but it was unclear why the two forms exist. Therefore, we focused on the two isoforms to examine the roles of the cytoplamic tail of GlcAT-P.

First, the two isoforms were expressed in mammalian cells to check the expression levels of the product HNK-1, and we found that the shorter isoform exhibited significantly higher biosynthetic activity (Fig. 4A) (15). On the contrary, as expected by the same catalytic domains, the two isoforms exhibited comparable specific activity in vitro (Fig. 4B).

Next, we examined their subcellular localization and we revealed that the longer isoform is localized mainly in the Golgi and partly in the ER, while the shorter one is localized strictly in the Golgi (Fig. 4C). GlcAT-P cannot serve as a functional enzyme in the ER because it modifies the end of complex-type glycans. Based on these results, we speculated that the difference in localization was the cause of the distinct biosynthetic activity.

Considering the mechanism underlying the different subcellular localization, we focused on the dibasic motif of GlcAT-P. This motif in the cytoplasmic tail is directly recognized by Sar1 which is one of the COPII vesicle components and this binding plays an important role in the transport of glycosyltransferases from the ER to the Golgi (12). Since P-N13 is present close to this motif, we hypothesized
ムに着目し、GlcAT-P の細胞質領域の役割について解析した。 まずこの二種のアイソフォームを動物細胞に発現させ、 産物である HNK-1 糖鎖の発現量を見ると、短い細胞質領域の 酵素の方がはるかに高い生合成活性を示すことがわかった(図 $4 \mathrm{~A})(15) 。$ 一方、同一の触媒領域を持つ事から想像される通り、 発現させた二種のアイソフォームのインビトロに抢ける比活 性は同程度であった (図 4B)。

次に細胞内局在を見たところ、長いアイソフォームは 主にゴルジ体と一部 ERに局在するのに対して、短いアイソ フォームはほぼゴルジ体に局在することがわかった（図 4C)。 GlcAT-P は複合型糖鎖の末端を修飾することから、ERに打い ては機能できないと考えられ、この局在の差が生合成活性の 差を反映しているのではないかと推察した。

この局在の差を生み出す原因として、GlcAT-P の持つ dibasic motifに着目した。細胞質領域内に存在するこのモチー フは、COPII 小胞の構成因子 Sar1により認識され、糖転移酵 素を ER からゴルジ体に輸送するのに重要であるとの報告が ある(12)。GlcAT-P のアイソフォームの差である13 アミノ酸 はこのモチーフの近傍に存在していることから、13アミノ酸 がこの輸送過程を阻害して一部の酵素を ER に留めるのでは ないかと考えた。実際、このモチーフが GlcAT-P のゴルジ局 


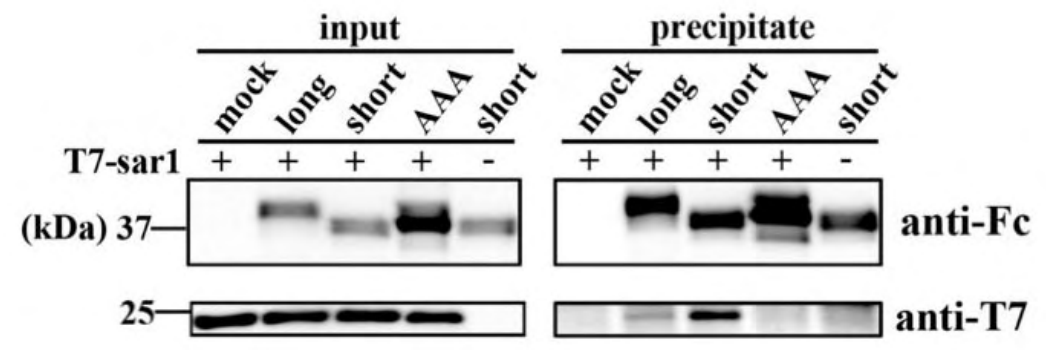

Fig. 5. Interaction between chimeric GlcAT-Ps and Sar1. Neuro2A cells were transfected with Fc-tagged lGlcAT-P, sGlcAT-P, or P-AAA (mutant GlcAT-P lacking the dibasic motif) expression plasmid, or the empty plasmid (mock). Cells were lysed and incubated with recombinant T7 tagged-Sar1, followed by incubation with Protein $G$ beads. The lysate mixture before precipitation (left panels) and the proteins precipitated with the beads (right panels) were Western blotted with anti-human IgG-Fc pAb (upper panels) or anti-T7 mAb (lower panels). This figure was modified from Kizuka et al. J. Biol. Chem. (2009)

that P-N13 interferes with this transport process to retain some population of the long isoform in the ER. Actually, we demonstrated that the motif is essential for the Golgi localization of GlcAT-P and that P-N13 weakened the binding of Sar1 to the motif (Fig. 5). These results suggest that the presence of P-N13 controls the intracellular transport of GlcAT-P via Sar-1 binding, leading to the regulation of the biosynthetic activity.

\section{Concluding Remarks}

As shown in this study, the regulation mechanism of intracellular activity of HNK-1-related enzymes is complicated. Recently, it was shown that the inner $N$-acetyllactosamine of HNK- 1 is predominantly biosynthesized by $\beta 4$ GalT-II in the brain (16). However, it is still unclear as to the degree the enzyme complex contributes to the biosynthesis in the brain or how the two isoforms are separately used in the brain, corresponding to a biologically significant event such as regulation of neural plasticity. Further studies are needed to answer these questions and to elucidate the regulatory mechanisms of other glycosyltransferases.
在に必須であること、また 13 アミノ酸の存在により Sar1 と モチーフとの結合が弱くなることが pull down 実験によって確 かめられた (図 5)。これらの結果をまとめると、13アミノ酸 の存在はSar1を介した細胞内輸送プロセスを制御することで、 GlcAT-P の生合成活性を調節していると考えられる。

D. おわりに

本研究で示した通り、HNK-1 合成に関わる酵素一つをとっ てみても、細胞内における活性制御機構は複雑であることが わかる。また最近では、HNK-1 の内部の $N$ - アセチルラクトサ ミンが主に $\beta 4$ GalT-IIにより生合成されるという興味深い知 見も得られている(16)。さらに上述の複合体が脳組織でどれだ け糖鎖生合成に寄与しているのか、あるいは二種の GlcAT-P アイソフォームがどのような条件で使い分けられるのかなど、 不明な点がまだ多く残されており、他の多くの転移酵素の活 性制御機構の解明も含め、今後の解析が待たれる。

\section{References}

1. Varki, A. (1998) Trends in Cell Biol. 8, 34-40.

2. de Graffenried, C. L., and Bertozzi, C. R. (2004) Curr. Opin. Cell Biol. 16, 356-363.

3. Sugimoto, I., Futakawa, S., Oka, R., Ogawa, K., Marth, J. D., Miyoshi, E., Taniguchi, N., Hashimoto, Y., and Kitazume, S. (2007) J. Biol. Chem. 282, 34896-34903.

4. Chen, C., Ma, J., Lazic, A., Backovic, M., and Colley, K. J. (2000) J. Biol. Chem. 275, 13819-13826

5. Morita, I., Kakuda, S., Takeuchi, Y., Itoh, S., Kawasaki, N., Kizuka, Y., Kawasaki, T., and Oka, S. (2009) J. Biol. Chem. $284,30209-30217$.

6. Kleene, R., and Schachner, M. (2004) Nat.Rev. Neurosci. 5, 195-208.

7. Morita, I., Kizuka, Y., Kakuda, S., and Oka, S. (2008) J. Biochem. 143, 719-724.

8. Yamamoto, S., Oka, S., Inoue, M., Shimuta, M., Manabe, T., Takahashi, H., Miyamoto, M., Asano, M., Sakagami, J., Sudo, K., Iwakura, Y., Ono, K., and Kawasaki, T. (2002) J. Biol. Chem. 277, 27227-27231.

9. Morita, I., Kakuda, S., Takeuchi, Y., Kawasaki, T., and Oka, S. (2009) Neuroscience 164, 1685-1694.

10. Kizuka, Y., Matsui, T., Takematsu, H., Kozutsumi, Y., Kawasaki, T., and Oka, S. (2006) J. Biol. Chem. 281, $13644-13651$.

11. Breton, C., Mucha, J., and Jeanneau, C. (2001) Biochimie 83, 713-718.

12. Giraudo, C. G., and Maccioni, H. J. (2003) Mol. Biol. Cell 14, 3753-3766.

13. Tu. L., Tai. W. C., Chen. L., and Banfield, D. K. (2008) Science 321, 404-407. 
14. Yamamoto, S., Oka, S., Saito-Ohara, F., Inazawa, J., and Kawasaki, T. (2002) J. Biochem. 131, 337-347.

15. Kizuka, Y., Tonoyama, Y., and Oka, S. (2009) J. Biol. Chem. 284, 9247-9256

16. Yoshihara, T., Sugihara, K., Kizuka, Y., Oka, S., and Asano, M. (2009) J. Biol. Chem. 284, 12550-12561.

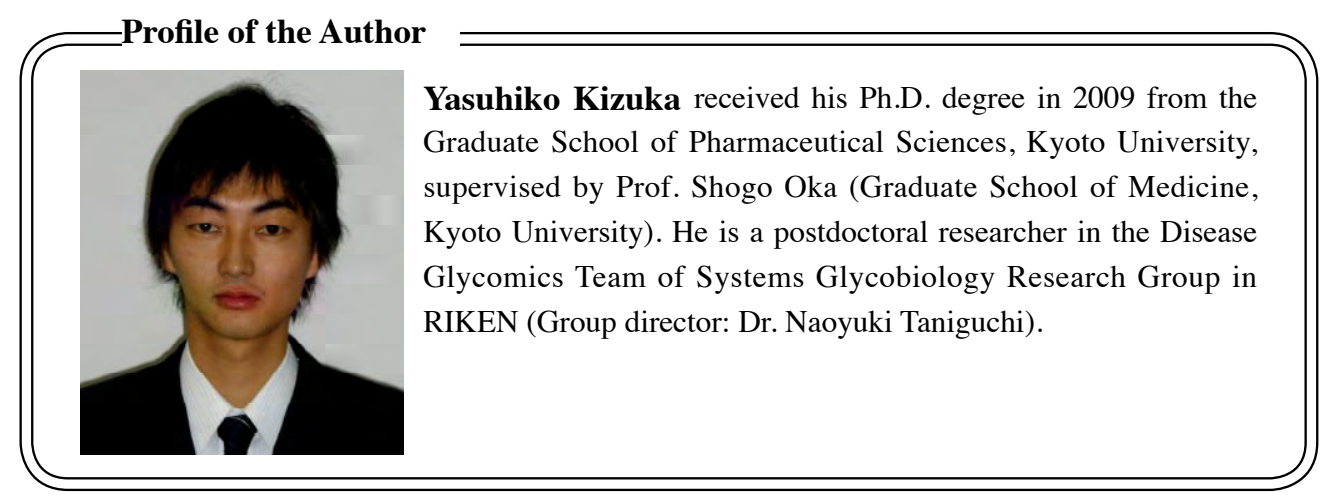

